Part of Journal of Research of the National Bureau of Standards, Volume 18, May 1937

\title{
INTERFERENCE MEASUREMENTS OF WAVE LENGTHS IN THE ULTRAVIOLET SPECTRUM OF IRON
}

\author{
By William F. Meggers and Curtis J. Humphreys
}

\section{ABSTRACT}

The wave lengths of 252 ultraviolet lines (3498 to 2101 A) characteristic of the international iron arc were measured relative to cadmium, krypton or neon standards. These measurements were made with Fabry-Perot étalon interferometers and stigmatic spectrographs. Invar étalons of $2,3,5,7.5$, or $10 \mathrm{~mm}$ length, and aluminized quartz plates were used. The spectrographs consisted of a concave grating, a Littrow quartz, or a Cornu quartz instrument. With the first, simultaneous exposures were obtained of red neon lines in the first-order spectrum, and of ultraviolet iron lines in the overlapping second-order spectrum. The use of quartz spectrographs required alternate exposures of primary and secondary sources. The final values in many cases are given to eight figures since calculations of probable error and tests of relative value by means of the combination principle indicated average errors smaller than $0.0005 \mathrm{~A}$.

\section{CONTENTS}

I. Introduction

II. Experiments

III. Measurements

IV. Corrections

V. Results

VI. References

\section{INTRODUCTION}

Nearly half a century ago Kayser and Runge [1] ${ }^{1}$ proposed the arc spectrum of iron as a source of wave-length standards for spectroscopic measurements. Since that time very considerable effort has been exerted to select suitable standards, refine their values, and to extend measurements throughout a long range of spectrum [2]. Although steady progress has been made toward the establishment of a trustworthy, homogeneous system of standards, the task is still unfinished.

The greatest advance followed the invention and use of interferometers, a primary standard being thus determined by comparing the red radiation from cadmium with the meter, and secondary standards from the arc spectrum of iron being measured relative to this primary standard. Since 1919 this program has been sponsored by the International Astronomical Union, which, in 1928, adopted 244 values (3370.787 to $6677.993 \mathrm{~A}$ ) of iron lines as international secondary standards, and recommended that the system be extended both to longer and to shorter waves [3]. Interference measurements of the shorter waves of iron have since been published by Burns and Walters

\footnotetext{
1 Numbers in brackets refer to literature citations at the end of this paper.
} 
[4] and by C. V. Jackson [5], but according to rule no line may be considered for adoption as an international secondary standard until three independent and concordant determinations exist. In the present paper another series of measurements in the ultraviolet spectrum of iron (3500 to $2100 \mathrm{~A}$ ) is reported. Other measurements by Buisson and Fabry [6], by Burns [7], and by Pressentin [8] will not be considered here since they cover only a part of this range with relatively few observations, and have been adequately discussed by Jackson [5].

\section{EXPERIMENTS}

The results reported in this paper were derived from interference spectrograms of cadmium, neon, krypton, and iron spectra obtained by employing combinations of Fabry-Perot interferometers and stigmatic spectrographs.

The primary sources consisted of cadmium lamps of the type specified by the International Committee on Weights and Measures [9] or of Geissler tubes containing pure neon or krypton. On account of frequent fracture of the cadmium lamps owing to unfortunate choice of glass whose expansion differed from that of the sealed-in wires, the majority of spectrograms were exposed either to neon or to krypton sources.

The secondary source was the iron arc specified by the International Astronomical Union for the production of secondary and tertiary standards [10]. It consisted of an iron arc operated at 220 volts with 5 amperes at a length of $15 \mathrm{~mm}$, an iron rod $7 \mathrm{~mm}$ in diameter serving as the upper pole (cathode), and a bead of iron oxide on a massive iron rod as the lower pole (anode). The upper rod was surrounded by a 2-inch brass cylinder bored with vertical holes to act as a heat radiator. An image of threefold magnification was projected on the interferometer with an aluminized mirror of $1-\mathrm{m}$ focal length, and a diaphragm selected light from the central 1.5-mm zone of the 15 -mm-arc flame.

Crystal quartz plates coated with evaporated aluminum were used in the étalon type of Fabry-Perot interferometer. The two plates produce respectively right-handed and left-handed polarization, both plates being cut with faces perpendicular to the optic axes and polished accurately plane. A small angle between surfaces of each plate prevented intersurface reflections. Etalons of three invar rods separated the aluminized surfaces either $2,3,5,7.5$, or $10 \mathrm{~mm}$.

An excellent quartz-fluorite achromatic lens (made by Carl Zeiss) of $25-\mathrm{cm}$ focal length was employed for imaging interference patterns on the spectrograph slits.

Three different spectrographs were used in making the observations. The first was an Anderson ruled grating of $650-\mathrm{cm}$ radius mounted to perform stigmatically [11]. A compromise between horizontal and vertical focus was adopted for $15 \mathrm{~cm}$ on either side of the axis or grating normal, and observations were made simultaneously in the first two orders of grating spectra. Since the dispersion is $10 \mathrm{~A} / \mathrm{mm}$ in the first order, it was possible to record on a 10 -inch plate 4700 to $7200 \mathrm{~A}$ in this order and simultaneously 2350 to $3600 \mathrm{~A}$ in the second order. By filtering the iron light through a piece of Corex A glass the ultraviolet spectrum was photographed in the second order, and simultaneously in the first order the neon spectrum was superposed 
when neon light was reflected from the rear surface of the Corex A filter or from a plane quartz mirror. The transmission of the Corex A filter set a limit on the iron spectrum near 2600 A. It was found that the dispersion was sufficient to prevent confusion of overlapping orders if the slit was not too wide, so that many exposures were made with both orders of iron spectra present as well as the neon spectrum. Line identification was facilitated by the difference in scale of interference patterns in first- and second-order grating spectra. From these grating spectrograms, measurements of iron lines down to $2388 \mathrm{~A}$ were secured. This series of iron and neon comparisons is the most reliable because of strict simultaneity of exposure under identical optical conditions and no disturbance of the apparatus.

In order to observe the shorter ultraviolet these grating spectrograms were supplemented by alternate exposures to krypton and iron with a Littrow type quartz spectrograph (Hilger E1). Since it is impossible with an instrument of this type to observe the visible (4400 A) and the ultraviolet (below $2500 \mathrm{~A}$ ) with a single adjustment, we tried the procedure which Jackson used [5]. The krypton (or cadmium) spectrum was photographed with the spectrograph set for visible light, and then the spectrograph was changed (prism rotated, lens refocused, and the plate tilted) to record the ultraviolet iron spectrum, followed by a return to the first setting for a second krypton (or cadmium) exposure. In this way, the iron lines (2700 to $2100 \mathrm{~A}$ ) were compared with krypton standards (4273 to $4502 \mathrm{~A}$ ) or with the cadmium standard (6438 A). By selecting for measurement only those spectrograms which showed no serious differences between the first and last exposures self-consistent results were obtained, but when these were compiled, it was distressing to find them systematically $0.0025 \mathrm{~A}$ higher than for the same lines measured relative to neon with the grating spectrograph.

Then the ultraviolet (2813 to $2100 \mathrm{~A}$ ) of iron was compared again with krypton standards (4273 to $4502 \mathrm{~A}$ ) by exposing them alternately in a Cornu prism spectrograph (Hilger E2) which covers the entire range with a 10 -inch plate. In this case, it was necessary only to rack the plate down for successive exposures without otherwise changing the spectrograph adjustments. The results of these measurements were in good agreement with those of the grating spectrograms, and it was concluded that those obtained with the $E 1$ spectrograph were $0.0025 \mathrm{~A}$ too large. Seeking the explanation for this discrepancy we investigated the effect of spectrograph focus on the fractional order of interference and found variations of this order of magnitude. It appears that systematic errors may be introduced unless exactly the same type of focus is used in spectrograph settings for different spectral regions. The values of $E 1$ spectrograms were finally reduced by $0.0025 \mathrm{~A}$ and averaged with the other two series.

Finally, another series of observations was made with the $E 1$ spectrograph after careful investigation of its horizontal and vertical focus for different spectral regions and choosing the same compromise in each. In this last series the interval 2400 to $2100 \mathrm{~A}$ was remeasured relative to krypton standards (4273 to $4502 \mathrm{~A}$ ) with $2-, 3-$, and 5-mm étalons, the dispersion of phase at reflection being determined again from 2- and 5-mm values. After applying the proper corrections for standard air density and dispersion of phase, these results were averaged with the others. 
For the grating spectrograms we employed Eastman $144 \mathrm{~F}$ plates. The same, or Eastman 33, emulsions were used in making the prism spectrograms, except in the shortest ultraviolet (2400 to $2100 \mathrm{~A}$ ) where observations were made with Schumann plates having greater sensitivity and contrast.

On account of the considerable range of intensity of iron lines suitable as standards, the best interference measurements require a variety of exposures, short ones for strong lines, long ones for weak lines, and intermediate ones for the remainder. The exposures with the grating spectrograph ranged from 5 minutes to an hour. With the prism spectrographs they ranged from 5 seconds to 30 minutes for iron and averaged about 5 minutes for cadmium or krypton. When making long exposures to the iron arc a quartz cell containing water was usually placed near the interferometer to absorb most of the heat radiation.

Accurate alignment of the light sources, condensers, interferometer, ring telescope, and spectrographs was effected in each case by placing an incandescent lamp at the center of the plate holder and centering each piece of apparatus in the light beam emerging from the slit in reverse order. Mirrors and lenses were so placed that each light source was first focused on the interferometer and again on the grating or prism of the spectrograph.

The interferometer plates were adjusted parallel by observing Haidinger's fringes when diffusely illuminated by light from a mercury lamp or a neon lamp. After adjustment they were allowed to stand for some hours and tested. If no further adjustment was required they were oriented so that the center of the interference patterns fell on the center of the spectrograph slit. This was accomplished in each case by observing, with magnification at the focus, the images of a wide slit and then reducing the slit width to $1 / 10$ or $1 / 20 \mathrm{~mm}$ for exposures. If the fringes are not accurately centered on the slit systematic errors will appear in their measurement.

Typical interference spectrograms are reproduced in figures 1 and 2.

\section{MEASUREMENTS}

These interference spectrograms were measured with a micrometer originally designed by Dr. Keivin Burns and constructed in the Bureau's instrument shop about 24 years ago. All interference measurements of wave lengths reported by our spectroscopic laboratory have been made with it, but its description has been neglected. It has a screw of $1 / 2 \mathrm{~mm}$ pitch, a revolution counter ${ }^{2}$ and head with 100 divisions, which moves a microscope (and reticule) across the interference pattern. Figure 3 illustrates this interference measuring device.

In measuring the grating spectrograms the diameters of three neon rings and five iron rings were determined. The same is true of cadmium and iron rings on prism spectrograms, but the number of krypton and iron rings measured was usually three and four respectively. This procedure resulted in measuring about the same over-all size of interference patterns for both primary and secondary standards, which was thought advisable to minimize errors due to possible distortion in the image forming systems. Such distortion would be

${ }^{2}$ The adaptation of a commercial counter was suggested by Mr. O. G. Lange, chief of the Bureau's instrument shop. 


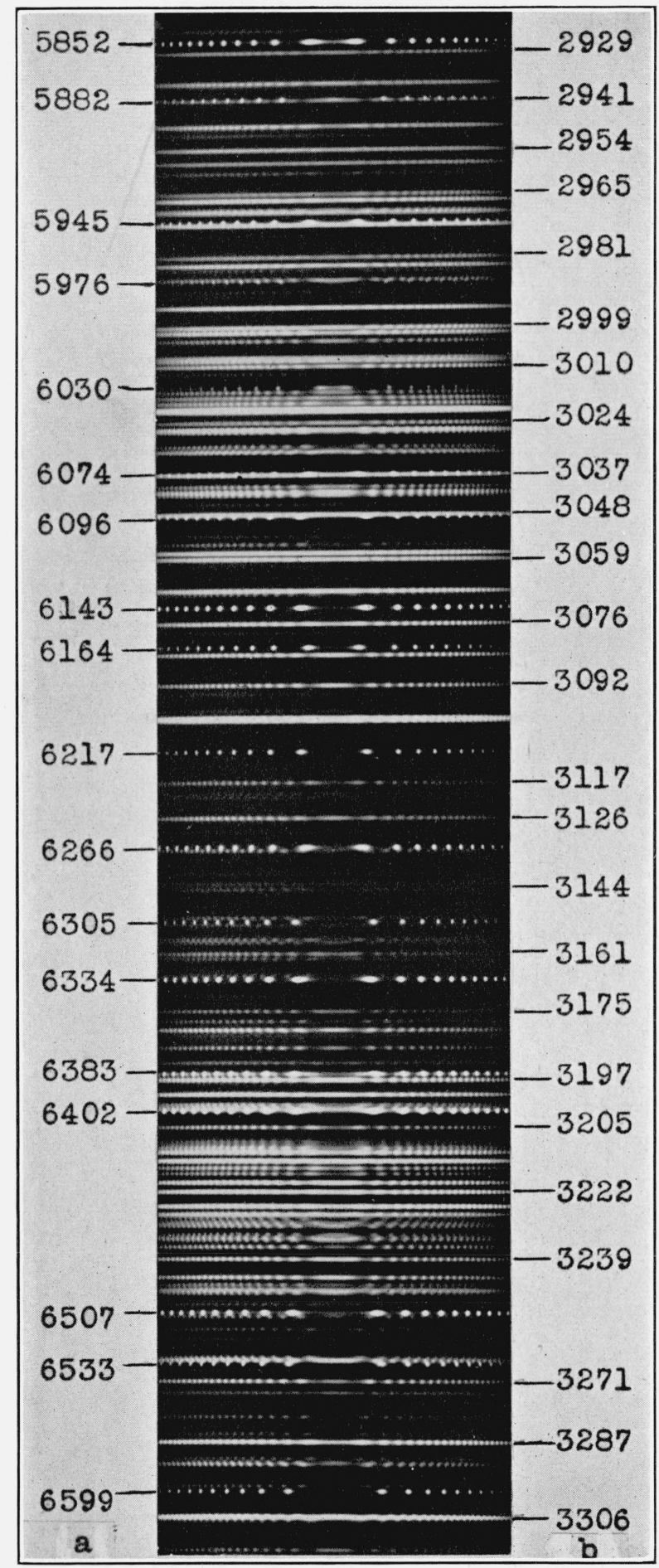

Figure 1.-Fabry-Perot interference patterns of neon and iron (5-mm étalon) photographed simultaneously, (a) neon spectrum in gratings first order, and (b) iron in second. 


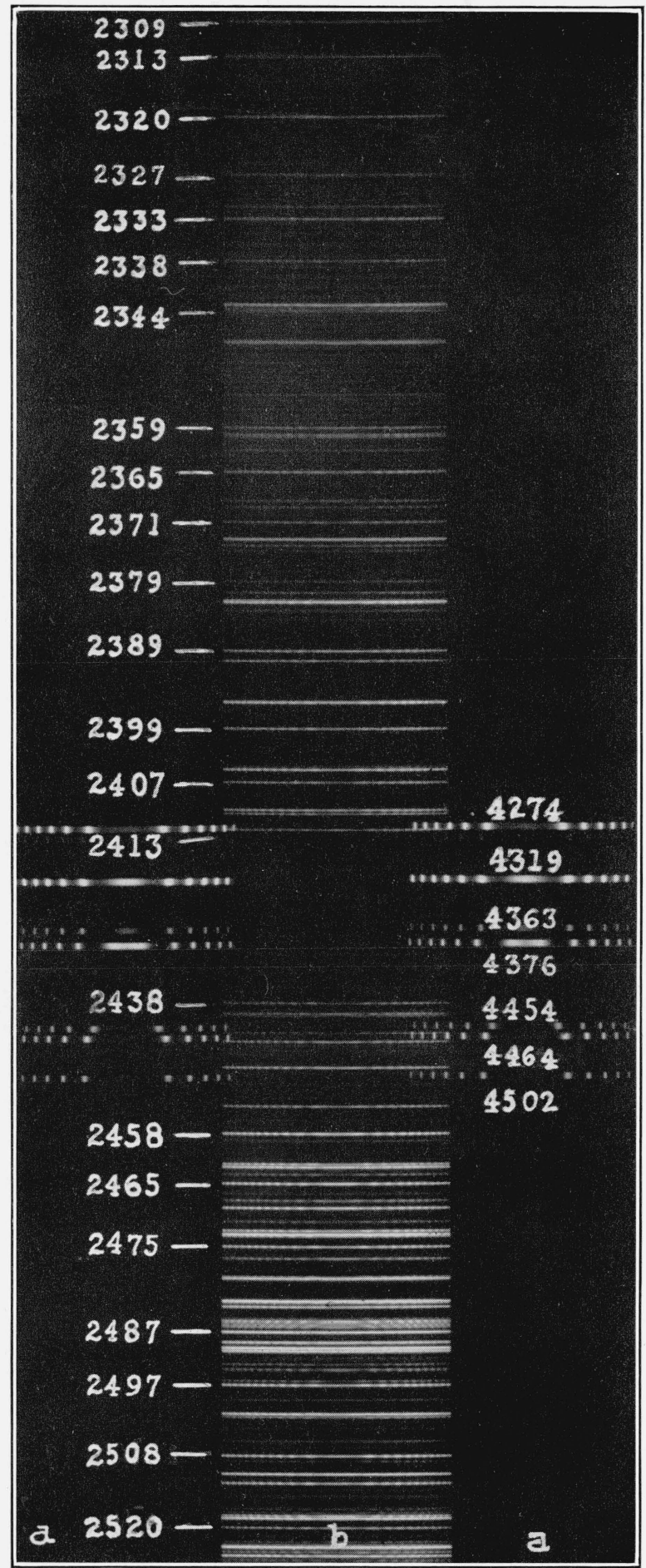

Figure 2.-Fabry-Perot interference patterns of (a) krypton, and (b) iron $(5 \mathrm{~mm}$ étalon) photographed alternately with different settings of quartz Littrow spectograph. 
revealed by slightly different fractional orders of interference from successive ring diameters, but no differences of this kind could be detected. The measured ring diameters were squared with the aid of Gauss's table of squares, and the average difference of squares for each line was plotted against wave length. A straight line was drawn to fit these points and for each wave length the value indicated by this line was divided into the successive squares of measured ring diameters to obtain the fractional order of interference at the center of the pattern. Although the interpolated value rarely differed from the observed by more than 1 percent, this procedure causes all the measurements on each plate to contribute to the accuracy of determining the fractional-order denominator for each wave length. For making the divisions a 20 -inch slide rule was found most convenient and rapid.

The interference path or double étalon distance was found either from cadmium, krypton, or neon lines, the correct order number in every case being readily deduced by the method illustrated for neon by Meggers [12]. When cadmium was used, the value $6438.4696 \mathrm{~A}$ for its red radiation served as the primary standard. When neon was employed, a group of six lines (6304.7892, 6334.4279, 6382.9914, $6506.5279,6532.8824,6598.9529$ A), with the center of gravity at $6437 \mathrm{~A}$, was regarded as identical with the primary standard [13]. Substituting krypton for the primary standard, the separation of interferometer plates was determined from six to eight blue lines (4273.9700, 4318.5525, 4319.5797, 4362.6423, 4376.1220, 4453.9179, 4463.6902, $4502.3547 \mathrm{~A}$ ), whose values have been accurately measured relative to cadmium or neon and have been adopted as standards by the International Astronomical Union [14]. Within the error of observation, our comparisons of iron wave lengths with these three different primary standards all yielded the same final values.

Since the general theory and method of comparing wave lengths with the Fabry-Perot interferometer have been given many times in other papers [15] no further details are required here.

\section{CORRECTIONS}

Interference comparisons of wave lengths require corrections for deviations of atmospheric density from standard conditions (dry air at $15^{\circ} \mathrm{C}$ and $760 \mathrm{~mm}$ ), and for the dispersion of phase change at reflection from the interferometer surfaces. Both corrections are important when the primary and secondary standards are in different spectral regions, and are especially large for the ultraviolet, where the dispersion curve of air rises steeply and the reflecting properties of surfaces usually change most rapidly with wave length.

The first correction was derived from observations of the mean air temperature and barometric pressure for each exposure. The air temperature near the interferometer was usually between 23 and $24^{\circ}$ $\mathrm{C}$, and the barometer was generally a little under normal so that these corrections were always negative, amounting to $-0.0032 \mathrm{~A}$ for $2100 \mathrm{~A}$ relative to $4400 \mathrm{~A}$ in extreme cases. When ultraviolet lines are measured relative to blue krypton lines instead of red cadmium or neon the corrections are reduced by the difference of their values at 4400 and $6400 \mathrm{~A}$. In all cases our corrections for standard air density were taken from the tables prepared for this purpose by Meggers and Peters [16]. Separate tables of corrections for temperature deviations and 
for pressure deviations from normal were calculated relative to 6000 A by Jackson [17], who was apparently unaware that the combined result is obtainable relative to any fixed point from the tables referred to above.

After correcting to standard atmospheric conditions the apparent wave lengths calculated from interference measurements require an adjustment for the dependence of phase change at reflection upon wave length. This phase correction is readily obtained from the wave-length comparisons, if these are made with a variety of étalons [12]. In the present instance consistent and reliable results were given by a comparison of the data from 7.5- and 2-mm étalons, or from 5- and 2-mm étalons.

For our aluminized quartz plates this phase correction was always negative in the ultraviolet, $-0.0008 \mathrm{~A}$ at $3500 \mathrm{~A}$, but increased rapidly beyond $2900 \mathrm{~A}$, and amounted to $-0.0040 \mathrm{~A}$ at $2500 \mathrm{~A}$ for the 5 -mm étalon. The largest correction of this type amounted to $-0.0205 \mathrm{~A}$ for $2100 \mathrm{~A}$ measured with $2-\mathrm{mm}$ étalons. The phase correction was extrapolated beyond $2153 \mathrm{~A}$ because no measurements were made there with étalons greater than $3 \mathrm{~mm}$. Only when these corrections are properly determined and applied will the final values for homogeneous lines be the same from all étalons.

\section{RESULTS}

Although the primary standard is defined to eight significant figures $(6438.4696 \mathrm{~A})$ and some eight-place values of secondary standards from noble gas spectra (neon, krypton) have been adopted $[13,14]$, the published values of iron lines have heretofore been restricted to seven-place values for the reason that iron lines excited in a high-temperature arc are intrinsically less sharp and more difficult to measure. ${ }^{3}$ The Doppler width of iron lines is 5 to 10 times that of the primary line, or of certain neon and krypton lines, and moreover the wave lengths of some iron lines have been found to vary from arc center to pole $[18,19]$. This pole effect is eliminated by taking light from a narrow central zone of a long arc flame and the sharpness $\lambda / \Delta \lambda$ of the average iron line is closely described by its limiting order of interference, $N=100,000$ approximately. This means that the total width of a line at $3000 \mathrm{~A}$ is about $0.03 \mathrm{~A}$, and to evaluate the wave length to $\pm 0.0003 \mathrm{~A}$ requires that the center of gravity be determined within $1 / 100$ of the width. Fortunately, no trouble on account of hyperfine structure need be feared because according to DeGier and Zeeman [20] the isotopic constitution of iron consists of 90.2 percent mass number $56 ; 6.5$ percent mass number 54 ; 0.5 percent mass number 58 ; and 2.8 percent mass number 57 . It may be assumed that observed spectral lines are due to mass 56 and any lines due to isotopes 54,57 , and 58 will be too faint to affect wavelength measurements of those from isotope 56 . The principal factor limiting the precision of wave-length measurement of iron lines (aside from pole effect and line width) is the overlapping of interference patterns of very close lines of comparable intensity. We presume that this explains a number of cases in which consistent results were obtained with individual étalons, but the final mean values from different étalons disagreed by many times the probable error of each.

\footnotetext{
${ }^{3}$ Burns and Walters [4] and Jackson [5] have published eight-place wave numbers taken from eight-place wave lengths before reducing to seven, but no analysis was presented to justify this procedure.
} 


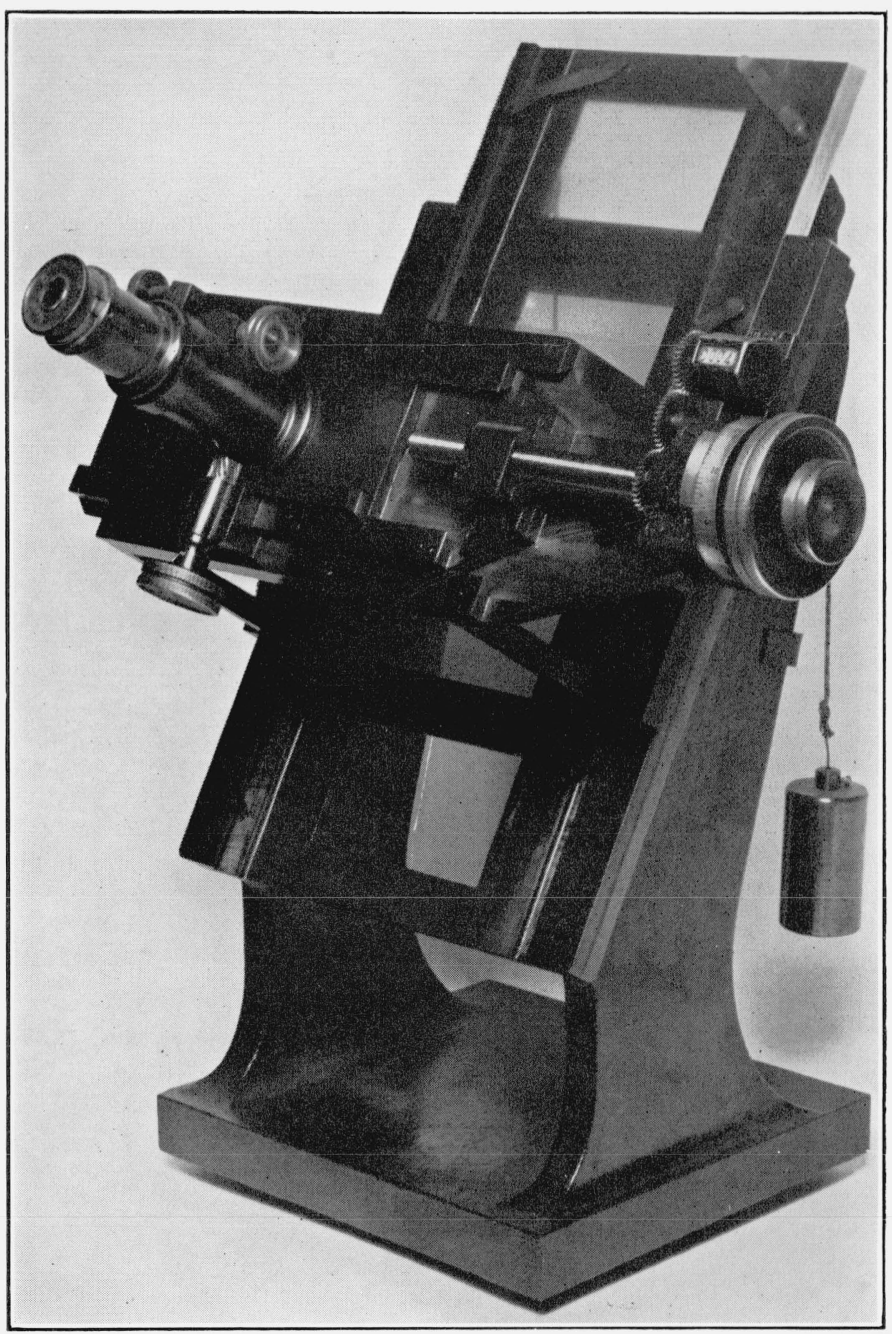

FIgURE 3.-Interference measuring machine. 
TABLE 1.-Individual values for various étalons ${ }^{1}$

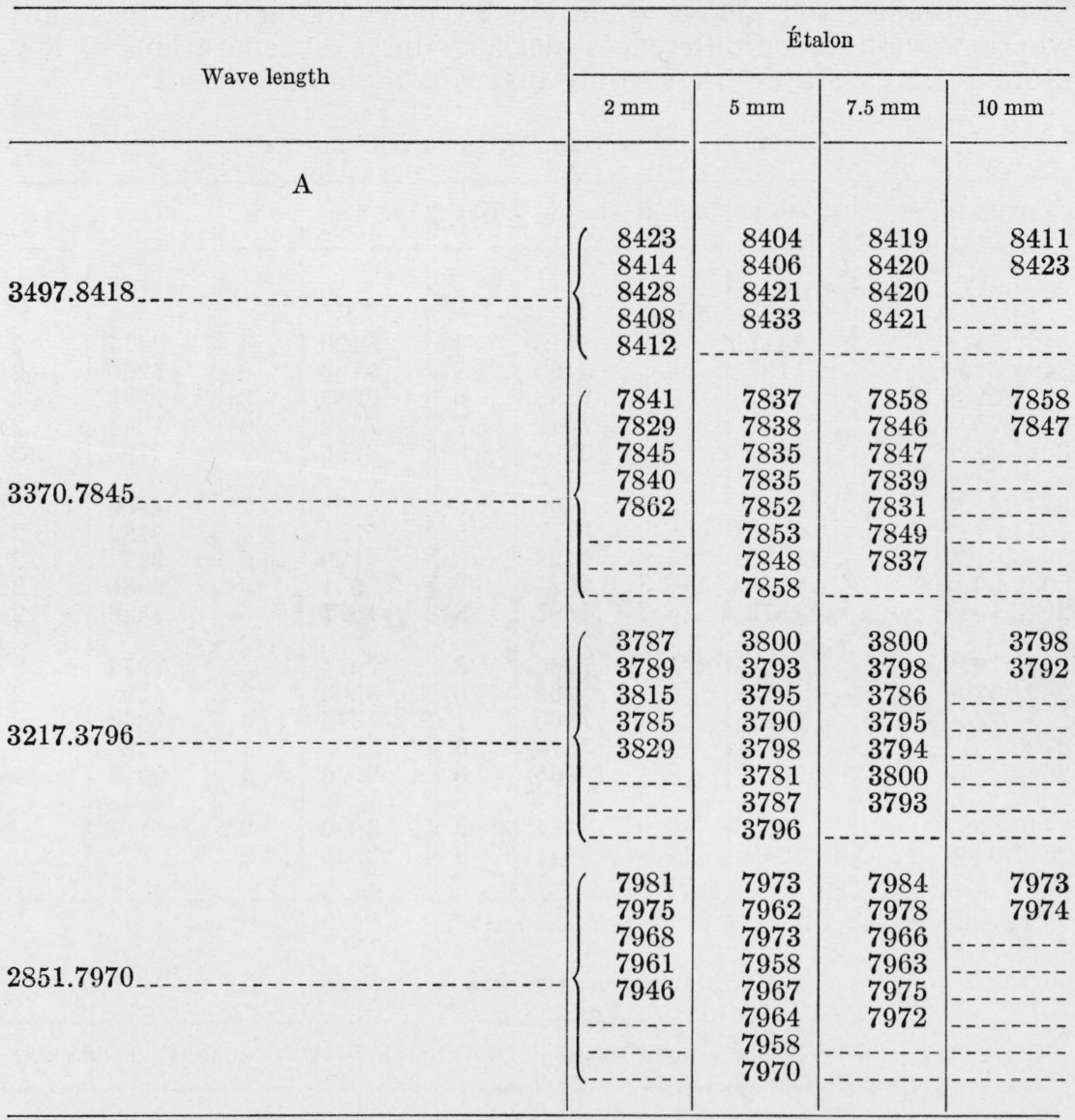

1 The whole number is shown only in the first column.

The concordance of fractional-order determinations from four or five successive rings for each line induced us to carry the wave-length calculations and corrections to the fourth-place decimal of an angstrom. When the corrected results were assembled and averaged the fourth-decimal place was retained with the intention of rounding to three places for publication. Since most of the lines were observed on 10 to 20 or more spectrograms and each value was based upon four or five measured ring diameters, each final value rests on from 80 to 200 bisections of ring segments. Where so many observations exist, it would seem that the least squares calculation of probable error might have physical significance. In taking the final means, the individual values from each étalon were given equal weight, and then the various étalon mean values were averaged by weighting according to the number of observations with each. For the majority of lines the calculated probable error of the mean was less than $0.0005 \mathrm{~A}$ both for étalon means (table 1) and for final means (table 2). Now the term analyses of iron spectra permit a crucial test of the precision of wave-length measurements by means of the 
combination principle. Most of the lines we have measured have been classified and among them are 20 pairs of eight-figure values where wave-number differences measure the level separations of low atomic-energy states. These are listed in table 3.

TABLE 2.-Mean values from various étalons a

\begin{tabular}{|c|c|c|c|c|c|c|c|c|}
\hline Wave length & 2 to $3 \mathrm{~mm}$ & Obs. & $5 \mathrm{~mm}$ & Obs. & $7.5 \mathrm{~mm}$ & Obs. & $10 \mathrm{~mm}$ & Obs. \\
\hline A & & & & & & & & \\
\hline $\begin{array}{l}3497.8418 \ldots \\
3401.5196 \ldots \\
3355.2285 \\
3286.7538 \\
3217.3796 \ldots\end{array}$ & $\begin{array}{l}8417 \\
5197 \\
2281 \\
7533 \\
3801\end{array}$ & $\begin{array}{l}5 \\
4 \\
2 \\
5 \\
5\end{array}$ & $\begin{array}{l}8415 \\
5193 \\
2283 \\
7542 \\
3793\end{array}$ & $\begin{array}{l}4 \\
8 \\
6 \\
7 \\
8\end{array}$ & $\begin{array}{l}8420 \\
5198 \\
2287 \\
7538 \\
3795\end{array}$ & $\begin{array}{l}4 \\
6 \\
3 \\
6 \\
7\end{array}$ & $\begin{array}{l}8417 \\
5200 \\
2293 \\
7544 \\
3795\end{array}$ & $\begin{array}{l}2 \\
2 \\
2 \\
2 \\
2\end{array}$ \\
\hline $\begin{array}{l}3175.4465 \\
3091.5777 \ldots \ldots \\
3015.9129 \\
2959.9924 \ldots \\
2912.1581 \ldots \\
\end{array}$ & $\begin{array}{l}4469 \\
5768 \\
9132 \\
9928 \\
1572\end{array}$ & $\begin{array}{l}5 \\
5 \\
5 \\
5 \\
5\end{array}$ & $\begin{array}{l}4460 \\
5777 \\
9128 \\
9921 \\
1587\end{array}$ & $\begin{array}{l}8 \\
8 \\
8 \\
8 \\
8\end{array}$ & $\begin{array}{l}4464 \\
5781 \\
9129 \\
9921 \\
1577\end{array}$ & $\begin{array}{l}7 \\
6 \\
6 \\
6 \\
5\end{array}$ & $\begin{array}{l}4469 \\
5782 \\
9134 \\
9930 \\
1586\end{array}$ & $\begin{array}{l}2 \\
2 \\
2 \\
2 \\
2\end{array}$ \\
\hline $\begin{array}{l}2851.7970 \\
2804.5200 \\
2755.7366 \\
2706.5812 \\
2643.9972\end{array}$ & $\begin{array}{l}7966 \\
5193 \\
7357 \\
5804 \\
9966\end{array}$ & $\begin{array}{l}5 \\
5 \\
5 \\
4 \\
3\end{array}$ & $\begin{array}{l}7966 \\
5202 \\
7360 \\
5816 \\
9965\end{array}$ & $\begin{array}{r}8 \\
10 \\
7 \\
5 \\
6\end{array}$ & $\begin{array}{l}7974 \\
5203 \\
7376 \\
5808 \\
9976\end{array}$ & $\begin{array}{l}6 \\
7 \\
4 \\
1 \\
4\end{array}$ & $\begin{array}{l}7974 \\
5205 \\
7364 \\
5820 \\
9986\end{array}$ & $\begin{array}{l}2 \\
2 \\
2 \\
1 \\
1\end{array}$ \\
\hline $\begin{array}{l}2413.3087-- \\
2327.3940\end{array}$ & $\begin{array}{l}3088 \\
3940\end{array}$ & $\begin{array}{l}10 \\
15\end{array}$ & $\begin{array}{l}3084 \\
3941\end{array}$ & $\begin{array}{l}6 \\
8\end{array}$ & $\begin{array}{l}3090 \\
3935\end{array}$ & $\begin{array}{l}2 \\
2\end{array}$ & & \\
\hline
\end{tabular}

a The whole number is shown only in the first column.

TABLE 3.-Energy-level differences

\begin{tabular}{|c|c|c|c|c|c|}
\hline Term symbols & Wave numbers & Differences & Term symbols & Wave numbers & Differences \\
\hline$a^{5} \mathrm{D}_{0}-a^{5} \mathrm{Di}_{\mathrm{i}}$ & $\begin{array}{l}28844.618-28754.676 \\
33804.031-33714.093 \\
43523.036-43433.091\end{array}$ & $\begin{array}{l}89.942 \\
89.938 \\
89.945\end{array}$ & $a^{7} \mathrm{D}_{4}-a^{7} \mathrm{D}_{b}^{\circ}$ & $\begin{array}{l}31027.036-30815.486 \\
31072.250-30860.694 \\
31482.556-31271.012\end{array}$ & $\begin{array}{l}211.550 \\
211.556 \\
211.544\end{array}$ \\
\hline$a^{5} \mathrm{D}_{1}-a^{5} \mathrm{D}_{2}^{2}$ & $\begin{array}{l}29028.750-28844.618 \\
33988.163-33804.031 \\
43479.629-43295.502\end{array}$ & $\begin{array}{l}184.132 \\
184.132 \\
184.127\end{array}$ & $a^{6} \mathrm{D}_{1}-a^{6} \mathrm{D}_{2}^{2}$ & $\begin{array}{l}38246.715-38132.274 \\
41538.728-41424.284 \\
42758.377-42643.934\end{array}$ & $\begin{array}{l}114.441 \\
114.445 \\
114.443\end{array}$ \\
\hline$a^{5} \mathrm{~F}_{4}-a^{5} \mathrm{~F}^{0}$ & $\begin{array}{l}43707.159-43523.036 \\
35983.665-35535.177\end{array}$ & 184.123 & $a^{8} \mathrm{D}_{2}-a^{6} \mathrm{D}_{3}^{\circ}$ & & $\begin{array}{l}\text { 194. } 926 \\
194.929\end{array}$ \\
\hline & $\begin{array}{l}373115.443-36866.941 \\
41001.740-40553.249\end{array}$ & $\begin{array}{l}448.502 \\
448.491\end{array}$ & $a^{6} \mathrm{D}_{3}-a^{6} \mathrm{D}_{4}^{\circ}$ & $\begin{array}{l}38474.191-38191.328 \\
42273.457-41990.584\end{array}$ & $\begin{array}{l}282.863 \\
282.873\end{array}$ \\
\hline
\end{tabular}

The average deviation from the mean is 0.0034 wave number, which corresponds to an average probable error of less than $0.0004 \mathrm{~A}$ in the relative values of these wave lengths. We feel that these experiences justify the retention of the fourth decimal place when the probable error of the final mean is less than $0.0005 \mathrm{~A}$. Our final values are exhibited in table 4, together with values quoted from Burns and Walters [4] and from Jackson [5] for purposes of comparison. The values measured by Burns and Walters apply to the iron arc at reduced pressure, and are not strictly comparable with the others unless corrected for pressure displacement. Comparison of $219 \mathrm{~B}$ and $W$ 
lines and $108 \mathrm{~J}$ lines with our values shows the following differences in Angstrom units:

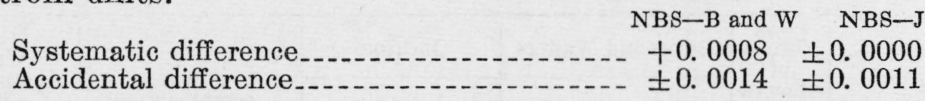

The systematic difference is of the expected order and sign for the displacement due to atmospheric pressure, but the accidental differences are two or three times our average probable error. If correction is made for the former, the averaging of three independent and concordant observations will yield satisfactory seven-place secondary standards of wave length throughout a considerable range of ultraviolet.

Our observations were purposely extended above $3370 \mathrm{~A}$ to test the agreement of the present series with the values adopted by the IAU [10]. For 13 lines (3370.7 to $3497.8 \mathrm{~A}$ ) there is an accidental difference of $0.0010 \mathrm{~A}$, and a systematic difference (NBS-IAU) $=$ $-0.0009 \mathrm{~A}$. This discrepancy would appear to be larger than the probable error of either set, but we are unable to account for it. It illustrates again the extreme difficulty of accurately determining the relative values of wave lengths widely separated in the spectrum. Assuming that this difference is not due to errors of focus for the primary and secondary lines and that the corrections for standard air density and dispersion of phase have been correctly made in each case, the only uncertainty (neglecting error of measurement) is a secondary correction due to water vapor in the air since interference measurements are always made in moist air. But the corrections for standard air density are taken from data applying to dry air. Considering the data on refraction and dispersion of steam by $\mathrm{C}$. and M. Cuthbertson [21], it is obvious that the correction for absolute humidity of average air must be a differential one of negligible magnitude for ordinary interference comparisons.

It may be recalled that the scale of secondary standards adopted by the IAU in 1928 was somewhat lower than the values of 1922 . This revision [22] ranged from $-0.001 \mathrm{~A}$ for 3370 to $4000 \mathrm{~A}$ to $-0.009 \mathrm{~A}$ for 6663 to $6750 \mathrm{~A}$. It appears probable from our measurements that the ultraviolet values may still be 1 part in 4 million too large.

Our final results are displayed in the first column of table 4 , the second column of which indicates the number of spectrograms on which each line was measured. The fractional values and number of observations reported by Burns and Walters [4] and by Jackson [5] are quoted in columns 3 and 4, respectively. In column 3 the letter c means computed value. Spectral-term combinations as given by Burns and Walters [4], by Catalán [23], and by Russell [24] are entered in column 5. Here odd multiplicities designate lines due to neutral atoms and even multiplicities designate those characteristic of singly ionized atoms. Vacuum wave numbers calculated from the data in column 1 with the aid of Kayser's Tabelle der Schwingungszahlen appear in the last column. 
TABLE 4.-Interference measurements of wave length in the ultraviolet spectrum of iron

\begin{tabular}{|c|c|c|c|c|c|c|c|}
\hline \multirow{2}{*}{$\begin{array}{l}\lambda_{\text {air }} \mathrm{A} \\
\text { NBS }\end{array}$} & \multirow{2}{*}{$\begin{array}{c}\text { Number } \\
\text { of } \\
\text { observa- } \\
\text { tions } \\
N\end{array}$} & \multicolumn{2}{|c|}{ Burns and Walters } & \multicolumn{2}{|c|}{ Jackson } & \multirow{2}{*}{$\begin{array}{l}\text { Term } \\
\text { combination }\end{array}$} & \multirow{2}{*}{$\begin{array}{c}\text { Wave } \\
\text { number } \\
\text { in } \\
\text { vacuum }\end{array}$} \\
\hline & & $\lambda$ & $N$ & $\lambda$ & $N$ & & \\
\hline $\begin{array}{l}3497.8418 \\
3490.5746 \\
3485.3415 \\
3476.7035 \\
3465.8622\end{array}$ & $\begin{array}{r}15 \\
5 \\
20 \\
14 \\
9\end{array}$ & $\begin{array}{l}841 \\
574 \\
339 \\
702 \\
860\end{array}$ & $\begin{array}{l}7 \\
4 \\
8 \\
6 \\
5\end{array}$ & $\begin{array}{l}843 \\
575 \\
342 \\
703 \\
863\end{array}$ & $\begin{array}{l}3 \\
3 \\
4 \\
1 \\
3\end{array}$ & $\begin{array}{c}a^{5} \mathrm{D}_{1}-a^{5} \mathrm{P}_{2}^{\circ} \\
a^{5} \mathrm{D}_{3}-a^{5} \mathrm{P}_{3}^{\circ} \\
a^{5} \mathrm{P}_{2}-\alpha^{5} \mathrm{P}_{1}^{\circ} \\
a^{5} \mathrm{D}_{0}-a^{5} \mathrm{P}_{1}^{\circ} \\
a^{5} \mathrm{D}_{1}-a^{5} \mathrm{P}_{1}^{\circ}\end{array}$ & $\begin{array}{l}28580.909 \\
28640.411 \\
28683.413 \\
28754.676 \\
28844.618\end{array}$ \\
\hline $\begin{array}{l}3445.1506 \\
3443.8774 \\
3427.1207 \\
3413.1335 \\
3407.4608\end{array}$ & $\begin{array}{l}20 \\
13 \\
16 \\
20 \\
18\end{array}$ & $\begin{array}{l}148 \\
878 \\
119 \\
131 \\
460\end{array}$ & $\begin{array}{r}11 \\
6 \\
9 \\
11 \\
9\end{array}$ & $\begin{array}{l}150 \\
878 \\
121\end{array}$ & $\begin{array}{l}2 \\
3 \\
5\end{array}$ & $\begin{array}{l}a^{5} \mathrm{P}_{2}-19 \mathrm{R}_{3}^{\circ} \\
a^{5} \mathrm{D}_{2}-a^{5} \mathrm{P}_{1}^{\circ} \\
a^{5} \mathrm{P}_{3}-18 \mathrm{R}_{4}^{\circ} \\
a^{5} \mathrm{P}_{2}-d^{3} \mathrm{D}_{3}^{\circ} \\
a^{5} \mathrm{P}_{3}-c^{3} \mathrm{~F}_{4}^{\circ}\end{array}$ & $\begin{array}{l}29018.021 \\
29028.750 \\
29170.679 \\
29290.219 \\
29338.979\end{array}$ \\
\hline $\begin{array}{l}\text { 3401. } 5196 \\
3399.3343 \\
3396.9772 \\
3383.9808 \\
3380.1111\end{array}$ & $\begin{array}{l}20 \\
21 \\
19 \\
22 \\
18\end{array}$ & $\begin{array}{l}518 \\
333 \\
974 \\
979 \\
110\end{array}$ & $\begin{array}{r}8 \\
10 \\
5 \\
8 \\
8\end{array}$ & $\begin{array}{l}522 \\
337\end{array}$ & $\begin{array}{l}4 \\
4\end{array}$ & $\begin{array}{l}a^{5} \mathrm{~F}_{4}-b^{5} \mathrm{P}_{3}^{\circ} \\
a^{5} \mathrm{P}_{2}-d^{3} \mathrm{D}_{2}^{\circ} \\
a^{5} \mathrm{~F}_{3}-b^{5} \mathrm{P}_{2}^{\circ} \\
a^{5} \mathrm{P}_{3}-c^{3} \mathrm{~F}_{3}^{\circ} \\
(\mathrm{Fe} \mathrm{I})\end{array}$ & $\begin{array}{l}29390.221 \\
29409.115 \\
29429.520 \\
29542.543 \\
29576.364\end{array}$ \\
\hline $\begin{array}{l}3370.7845 \\
3355.2285 \\
3347.9262 \\
3340.5659 \\
3337.6655\end{array}$ & $\begin{array}{l}22 \\
13 \\
11 \\
13 \\
10\end{array}$ & $\begin{array}{l}784 \\
228 \\
926 \\
565 \\
666\end{array}$ & $\begin{array}{l}8 \\
7 \\
3 \\
3 \\
2\end{array}$ & $\begin{array}{l}786 \\
229 \\
928 \\
566 \\
667\end{array}$ & $\begin{array}{l}4 \\
4 \\
4 \\
4 \\
4\end{array}$ & $\begin{array}{l}(\mathrm{Fe} \mathrm{I}) \\
(\mathrm{Fe} \mathrm{I}) \\
a^{3} \mathrm{P}_{2}-4 \mathrm{R}_{2}^{\circ} \\
a^{3} \mathrm{P}_{2}-2 \mathrm{R}_{2}^{\circ} \\
(\mathrm{Fe} \mathrm{I})\end{array}$ & $\begin{array}{l}29658.195 \\
29795.697 \\
29860.682 \\
29926.473 \\
29952.476\end{array}$ \\
\hline $\begin{array}{l}\text { 3328. } 8669 \\
\text { 3323. } 7374 \\
3314.7421 \\
\text { 3306. } 356 \\
\text { 3305. } 971\end{array}$ & $\begin{array}{r}19 \\
19 \\
21 \\
3 \\
3\end{array}$ & $\begin{array}{l}867 \\
735 \\
741 \\
352 \\
970\end{array}$ & $\begin{array}{l}5 \\
6 \\
7 \\
8 \\
9\end{array}$ & $\begin{array}{l}866 \\
737 \\
741\end{array}$ & $\begin{array}{l}4 \\
4 \\
4\end{array}$ & $\begin{array}{l}(\mathrm{Fe} \mathrm{I}) \\
(\mathrm{Fe} \mathrm{I}) \\
(\mathrm{Fe} \mathrm{I}) \\
a^{5} \mathrm{P}_{1}-e^{5} \mathrm{P}_{2}^{\circ} \\
a^{5} \mathrm{P}_{2}-e^{5} \mathrm{P}_{3}^{\circ}\end{array}$ & $\begin{array}{l}30031.644 \\
30077.990 \\
30159.610 \\
30236.10 \\
30239.62\end{array}$ \\
\hline $\begin{array}{l}3298.1328 \\
3286.7538 \\
3284.5892 \\
3280.2613 \\
3271.0014\end{array}$ & $\begin{array}{r}19 \\
20 \\
9 \\
19 \\
21\end{array}$ & $\begin{array}{r}132 \\
753 \\
588 \\
260 \\
0.999\end{array}$ & $\begin{array}{r}9 \\
10 \\
5 \\
8 \\
10\end{array}$ & $\begin{array}{l}131 \\
754 \\
587 \\
261 \\
001\end{array}$ & $\begin{array}{l}6 \\
6 \\
5 \\
5 \\
7\end{array}$ & $\begin{array}{l}a^{5} \mathrm{P}_{1}-4 \mathrm{R}_{2}^{\circ} \\
a^{5} \mathrm{P}_{\mathrm{s}}-e^{5} \mathrm{P}_{3}^{\circ} \\
a^{5} \mathrm{P}_{2}-e^{5} \mathrm{P}_{2}^{\circ} \\
\left(\mathrm{Fe}^{2}\right) \\
a^{5} \mathrm{P}_{2}-e^{5} \mathrm{P}_{1}^{\circ}\end{array}$ & $\begin{array}{l}30311.488 \\
30416.425 \\
30436.469 \\
30476.624 \\
30562.898\end{array}$ \\
\hline $\begin{array}{l}\text { 3257. } 5937 \\
3254.3628 \\
3244.1887 \\
3239.4362 \\
3236.2226\end{array}$ & $\begin{array}{l}19 \\
20 \\
21 \\
21 \\
22\end{array}$ & $\begin{array}{l}593 \\
363 \\
187 \\
434 \\
223\end{array}$ & $\begin{array}{r}7 \\
8 \\
10\end{array}$ & $\begin{array}{l}592 \\
362 \\
190 \\
437 \\
222\end{array}$ & $\begin{array}{l}5 \\
5 \\
7 \\
7 \\
7\end{array}$ & $\begin{array}{l}a^{5} \mathrm{P}_{3}-4 \mathrm{R}_{2}^{\circ} \\
(\mathrm{Fe} I) \\
a^{7} \mathrm{D}_{4}^{\circ}-34 \mathrm{~W}_{5} \\
a^{7} \mathrm{D}_{4}^{\circ}-33 \mathrm{~W}_{4} \\
a^{5} \mathrm{D}_{3}-a^{3} \mathrm{~F}_{4}^{\circ}\end{array}$ & $\begin{array}{l}30688.685 \\
30719.153 \\
30815.486 \\
30860.694 \\
30891.337\end{array}$ \\
\hline $\begin{array}{l}\text { 3225. } 7883 \\
\text { 3222. } 0682 \\
\text { 3217. } 3796 \\
\text { 3215. } 9398 \\
\text { 3205. } 3992\end{array}$ & $\begin{array}{l}17 \\
19 \\
22 \\
18 \\
20\end{array}$ & $\begin{array}{l}788 \\
067 \\
377 \\
939 \\
399\end{array}$ & $\begin{array}{r}10 \\
10 \\
9 \\
9 \\
9\end{array}$ & $\begin{array}{l}790 \\
069 \\
381 \\
940 \\
400\end{array}$ & $\begin{array}{l}7 \\
7 \\
7 \\
7 \\
7\end{array}$ & $\begin{array}{l}a^{7} \mathrm{D}_{5}^{\circ}-53 \mathrm{~W}_{6} \\
a^{7} \mathrm{D}_{5}^{\circ}-34 \mathrm{~W}_{5} \\
a^{7} \mathrm{D}_{5}^{0}-33 \mathrm{~W}_{4} \\
a^{7} \mathrm{D}_{2}^{0}-20 \mathrm{~W}_{2} \\
a^{7} \mathrm{D}_{1}^{\circ}-43 \mathrm{~W}_{1}\end{array}$ & $\begin{array}{l}\text { 30991. } 256 \\
31027.036 \\
31072.250 \\
31086.159 \\
31188.380\end{array}$ \\
\hline $\begin{array}{l}3200.4741 \\
3196.9288 \\
3191.6583 \\
3184.8948 \\
3178.0137\end{array}$ & $\begin{array}{r}9 \\
8 \\
9 \\
22 \\
16\end{array}$ & $\begin{array}{l}471 \\
927 \\
659 \\
894 \\
013\end{array}$ & $\begin{array}{r}10 \\
11 \\
9 \\
8 \\
6\end{array}$ & $\begin{array}{l}474 \\
930 \\
660 \\
896 \\
016\end{array}$ & $\begin{array}{l}7 \\
8 \\
7 \\
7 \\
7\end{array}$ & $\begin{array}{l}a^{7} \mathrm{D}_{2}^{\circ}-17 \mathrm{~W} \\
a^{7} \mathrm{D}_{4}^{\circ}-25 \mathrm{~W}_{5} \\
a^{5} \mathrm{D}_{4}-a^{3} \mathrm{D}_{3}^{\circ} \\
a^{5} \mathrm{D}_{3}-a^{3} \mathrm{~F}_{3}^{\circ} \\
a^{7} \mathrm{D}_{2}^{\circ}-27 \mathrm{~W}_{4}\end{array}$ & $\begin{array}{l}31236.375 \\
31271.012 \\
31322.649 \\
31389.164 \\
31457.126\end{array}$ \\
\hline $\begin{array}{l}3175.4465 \\
3160.6582 \\
3157.0388 \\
3143.9896 \\
3134.1113\end{array}$ & $\begin{array}{l}22 \\
22 \\
17 \\
12 \\
21\end{array}$ & $\begin{array}{l}445 \\
659 \\
038\end{array}$ & $\begin{array}{l}8 \\
6 \\
4\end{array}$ & $\begin{array}{l}447 \\
657 \\
042\end{array}$ & $\begin{array}{l}7 \\
2 \\
2\end{array}$ & $\begin{array}{l}a^{7} \mathrm{D}_{5}^{\circ}-25 \mathrm{~W}_{5} \\
a^{7} \mathrm{D}_{4}^{\circ}-16 \mathrm{~W}_{4} \\
a^{7} \mathrm{D}_{4}^{\circ}-13 \mathrm{~W}_{4} \\
(\mathrm{Fe}) \\
a^{5} \mathrm{~F}_{3}-c^{5} \mathrm{D}_{4}^{\circ}\end{array}$ & $\begin{array}{l}31482.556 \\
31629.854 \\
31666.113 \\
31797.540 \\
31897.757\end{array}$ \\
\hline
\end{tabular}


TABLE 4.-Interference measurements of wave length in the ultraviolet spectrum of iron-Continued

\begin{tabular}{|c|c|c|c|c|c|c|c|}
\hline \multirow{2}{*}{$\begin{array}{l}\lambda_{\text {air }} A \\
\text { NBS }\end{array}$} & \multirow{2}{*}{$\begin{array}{c}\text { Number } \\
\text { of } \\
\text { observa- } \\
\text { tions } \\
N\end{array}$} & \multicolumn{2}{|c|}{ Burns and Walters } & \multicolumn{2}{|c|}{ Jackson } & \multirow{2}{*}{$\begin{array}{c}\text { Term } \\
\text { combination }\end{array}$} & \multirow{2}{*}{$\begin{array}{c}\text { Wave } \\
\text { number } \\
\text { in } \\
\text { vacuum }\end{array}$} \\
\hline & & $\lambda$ & $N$ & $\lambda$ & $N$ & & \\
\hline $\begin{array}{l}\text { a } 3125.653 \\
3116.6329 \\
3091.5777 \\
3083.7419 \\
3075.7204\end{array}$ & $\begin{array}{l}14 \\
22 \\
21 \\
21 \\
20\end{array}$ & $\begin{array}{l}652 \\
632 \\
577 \\
741 \\
721\end{array}$ & $\begin{array}{r}3 \\
8 \\
11 \\
12 \\
9\end{array}$ & $\begin{array}{l}658 \\
633 \\
579 \\
743 \\
722\end{array}$ & $\begin{array}{r}7 \\
7 \\
12 \\
12 \\
9\end{array}$ & $\begin{array}{l}a^{7} \mathrm{D}_{5}^{\circ}-10 \mathrm{~W}_{4} \\
a^{5} \mathrm{~F}_{1}-c^{5} \mathrm{D}_{2}^{\circ} \\
a^{5} \mathrm{~F}_{1}-c^{5} \mathrm{D}_{0}^{\circ} \\
a^{5} \mathrm{~F}_{2}-c^{5} \mathrm{D}_{1}^{\circ} \\
a^{5} \mathrm{~F}_{3}-c^{5} \mathrm{D}_{2}^{\circ}\end{array}$ & $\begin{array}{l}31984.07 \\
32076.636 \\
32336.585 \\
32418.751 \\
32503.296\end{array}$ \\
\hline $\begin{array}{l}3067.2433 \\
3059.0874 \\
3057.4452 \\
3055.2631 \\
3047.6059\end{array}$ & $\begin{array}{l}14 \\
16 \\
12 \\
22 \\
12\end{array}$ & $\begin{array}{l}244 \\
090 \\
447 \\
264 \\
607\end{array}$ & $\begin{array}{l}9 \\
2 \\
6 \\
8 \\
2\end{array}$ & $\begin{array}{l}245 \\
085 \\
447\end{array}$ & $\begin{array}{r}10 \\
2 \\
9\end{array}$ & $\begin{array}{l}a^{5} \mathrm{~F}_{4}-c^{5} \mathrm{D}_{3}^{\circ} \\
a^{5} \mathrm{D}_{3}-b^{5} \mathrm{D}_{4}^{\circ} \\
a^{5} \mathrm{~F}_{5}-c^{5} \mathrm{D}_{4}^{\circ} \\
a^{3} \mathrm{~F}_{3}-c^{3} \mathrm{D}_{2}^{\circ} \\
a^{5} \mathrm{D}_{2}-b^{5} \mathrm{D}_{3}^{\circ}\end{array}$ & $\begin{array}{l}32593.122 \\
32680.015 \\
32697.567 \\
32720.920 \\
32803.128\end{array}$ \\
\hline $\begin{array}{l}\text { 3040. } 4281 \\
3037.3891 \\
3030.1491 \\
3024.0330 \\
3015.9129\end{array}$ & $\begin{array}{r}22 \\
9 \\
22 \\
21 \\
16\end{array}$ & $\begin{array}{l}427 \\
394 \\
148 \\
033\end{array}$ & $\begin{array}{r}11 \\
2 \\
10 \\
10\end{array}$ & 387 & 3 & $\begin{array}{l}a^{5} \mathrm{~F}_{4}-c^{5} \mathrm{~F}_{5}^{\circ} \\
a^{5} \mathrm{D}_{1}-b^{5} \mathrm{D}_{2}^{\circ} \\
(\mathrm{Fe} \mathrm{I}) \\
a^{5} \mathrm{D}_{1}-a^{3} \mathrm{P}_{2}^{\circ} \\
(\mathrm{Fe} \mathrm{I})\end{array}$ & $\begin{array}{l}32880.566 \\
32913.462 \\
32992.100 \\
33058.823 \\
33147.826\end{array}$ \\
\hline $\begin{array}{l}3009.5698 \\
3003.0311 \\
2999.5123 \\
2990.3923 \\
2987.2919\end{array}$ & $\begin{array}{r}20 \\
22 \\
10 \\
9 \\
21\end{array}$ & $\begin{array}{l}570 \\
031 \\
514 \\
391 \\
292\end{array}$ & $\begin{array}{r}11 \\
9 \\
9 \\
9 \\
12\end{array}$ & 291 & 9 & $\begin{array}{r}a^{5} \mathrm{~F}_{4}-c^{5} \mathrm{~F}_{4}^{\circ} \\
a^{5} \mathrm{~F}_{3}-c^{5} \mathrm{~F}_{2}^{\circ} \\
a^{5} \mathrm{~F}_{5}-c^{5} \mathrm{~F}_{5}^{\circ} \\
(\mathrm{Fe} \mathrm{I}) \\
a^{5} \mathrm{~F}_{4}-c^{5} \mathrm{~F}_{3}^{\circ}\end{array}$ & $\begin{array}{l}33217.689 \\
33290.012 \\
33329.065 \\
33430.705 \\
33465.401\end{array}$ \\
\hline $\begin{array}{l}\text { 2981. } 4448 \\
2965.2551 \\
2959.9924 \\
2957.3654 \\
2953.9400\end{array}$ & $\begin{array}{l}13 \\
11 \\
21 \\
11 \\
18\end{array}$ & $\begin{array}{l}445 \\
255 \\
991 \\
366 \\
939\end{array}$ & $\begin{array}{r}8 \\
14 \\
17 \\
9\end{array}$ & $\begin{array}{l}365 \\
940\end{array}$ & $\begin{array}{r}8 \\
10\end{array}$ & $\begin{array}{r}a^{5} \mathrm{D}_{3}-a^{3} \mathrm{P}_{2}^{\circ} \\
a^{5} \mathrm{D}_{0}-b^{5} \mathrm{~F}_{1} \\
(\mathrm{Fe} \mathrm{I}) \\
a^{5} \mathrm{D}_{1}-b^{5} \mathrm{~F}_{1}^{\circ} \\
a^{5} \mathrm{D}_{2}-b^{5} \mathrm{~F}_{2}^{\circ}\end{array}$ & $\begin{array}{l}33531.028 \\
33714.093 \\
33774.031 \\
33804.031 \\
33843.229\end{array}$ \\
\hline $\begin{array}{l}2941.3430 \\
2929.0081 \\
2920.6906 \\
2912.1581 \\
2899.4156\end{array}$ & $\begin{array}{l}14 \\
17 \\
14 \\
20 \\
13\end{array}$ & $\begin{array}{l}689 \\
159 \\
414\end{array}$ & $\begin{array}{l}19 \\
16 \\
19 \\
21 \\
21\end{array}$ & $\begin{array}{l}343 \\
008\end{array}$ & $\begin{array}{r}2 \\
10 \\
11\end{array}$ & $\begin{array}{r}a^{5} \mathrm{D}_{2}-b^{5} \mathrm{~F}_{1} \\
a^{5} \mathrm{D}_{3}-b^{5} \mathrm{~F}_{2}^{\circ} \\
a^{5} \mathrm{~F}_{2}-c^{3} \mathrm{~F}_{2}^{\circ} \\
a^{5} \mathrm{D}_{4}-b^{5} \mathrm{~F}_{3}^{\circ} \\
(\mathrm{Fe} \mathrm{I})\end{array}$ & $\begin{array}{l}33988.163 \\
34131.291 \\
34228.484 \\
34328.767 \\
34479.631\end{array}$ \\
\hline $\begin{array}{l}2895.0352 \\
2894.5050 \\
2877.3005 \\
2874.1722 \\
2869.3075\end{array}$ & $\begin{array}{l}13 \\
15 \\
12 \\
21 \\
20\end{array}$ & $\begin{array}{l}034 \\
504 \\
301 \\
172 \\
308\end{array}$ & $\begin{array}{l}19 \\
19 \\
19 \\
19 \\
18\end{array}$ & 307 & 8 & $\begin{array}{l}a^{3} \mathrm{~F}_{3}-c^{3} \mathrm{~F}_{3}^{\circ} \\
(\mathrm{Fe} \mathrm{I}) \\
a^{3} \mathrm{~F}_{4}-18 \mathrm{R}_{4}^{\circ} \\
a^{5} \mathrm{D}_{4}-a^{5} \mathrm{G}_{5}^{\circ} \\
a^{5} \mathrm{D}_{3}-a^{5} \mathrm{G}_{4}^{\circ}\end{array}$ & $\begin{array}{l}34531.798 \\
34538.122 \\
34744.631 \\
34782.445 \\
34841.412\end{array}$ \\
\hline $\begin{array}{l}2863.864 \\
2851.7970 \\
2845.5945 \\
2838.1193 \\
2832.4350\end{array}$ & $\begin{array}{l}10 \\
21 \\
15 \\
22 \\
21\end{array}$ & $\begin{array}{l}797 \\
595 \\
119 \\
437\end{array}$ & $\begin{array}{l}15 \\
22 \\
18 \\
21 \\
21\end{array}$ & $\begin{array}{l}120 \\
436\end{array}$ & $\begin{array}{r}7 \\
10\end{array}$ & $\begin{array}{c}a^{5} \mathrm{D}_{2}-a^{5} \mathrm{G}_{3}^{\circ} \\
a^{5} \mathrm{~F}_{1}-b^{5} \mathrm{G}_{2} \\
a^{5} \mathrm{~F}_{3}-c^{5} \mathrm{P}_{2}^{\circ} \\
a^{5} \mathrm{~F}_{2}-b^{5} \mathrm{G}_{2}^{\circ} \\
a^{5} \mathrm{~F}_{3}-b^{5} \mathrm{G}_{4}^{\circ}\end{array}$ & $\begin{array}{l}\text { 34907. } 63 \\
35055.334 \\
35131.740 \\
35224.266 \\
35294.951\end{array}$ \\
\hline $\begin{array}{l}\text { 2823. } 2753 \\
2813.2861 \\
2806.9840 \\
2804.5200 \\
2797.7751\end{array}$ & $\begin{array}{l}22 \\
17 \\
16 \\
25 \\
11\end{array}$ & $\begin{array}{l}274 \\
287 \\
985 \\
521 \\
775\end{array}$ & $\begin{array}{l}21 \\
19 \\
22 \\
21 \\
20\end{array}$ & $\begin{array}{l}276 \\
288 \\
985 \\
521\end{array}$ & $\begin{array}{l}3 \\
9 \\
8 \\
5\end{array}$ & $\begin{array}{l}a^{5} \mathrm{~F}_{3}-b^{5} \mathrm{G}_{3}^{\circ} \\
a^{5} \mathrm{~F}_{4}-b^{5} \mathrm{G}_{5}^{\circ} \\
a^{5} \mathrm{~F}_{4}-80 \mathrm{~B} \\
a^{5} \mathrm{~F}_{4}-b^{5} \mathrm{G}_{4}^{\circ} \\
a^{5} \mathrm{~F}_{4}-83 \mathrm{~B}\end{array}$ & $\begin{array}{l}35409.455 \\
35535.177 \\
35614.955 \\
35646.244 \\
35732.175\end{array}$ \\
\hline $\begin{array}{l}2781.8347 \\
2778.2205 \\
2767.5208 \\
2763.1078 \\
2755.7366\end{array}$ & $\begin{array}{r}6 \\
25 \\
19 \\
7 \\
19\end{array}$ & $\begin{array}{l}836 \\
221 \\
522 \\
108 \\
738\end{array}$ & $\begin{array}{l}18 \\
18 \\
15 \\
19 \\
19\end{array}$ & $\begin{array}{l}220 \\
525\end{array}$ & $\begin{array}{r}10 \\
9\end{array}$ & $\begin{array}{l}a^{5} \mathrm{~F}_{2}-d^{5} \mathrm{D}_{3}^{\circ} \\
a^{5} \mathrm{~F}_{5}-b^{5} \mathrm{G}_{5}^{\circ} \\
a^{5} \mathrm{~F}_{4}-d^{5} \mathrm{D}_{4}^{\circ} \\
a^{5} \mathrm{~F}_{2}-52 \mathrm{R}_{3}^{\circ} \\
a^{4} \mathrm{D}_{4}-a^{4} \mathrm{~F}_{3}^{\circ}\end{array}$ & $\begin{array}{l}35936.917 \\
35983.665 \\
36122.776 \\
36180.464 \\
36277.237\end{array}$ \\
\hline
\end{tabular}


TABLE 4.-Interference measurements of wave length in the ultraviolet spectrum of iron-Continued

\begin{tabular}{|c|c|c|c|c|c|c|c|}
\hline \multirow{2}{*}{$\begin{array}{l}\lambda_{\text {air } A} A \\
\text { NBS }\end{array}$} & \multirow{2}{*}{$\begin{array}{c}\text { Number } \\
\text { of } \\
\text { observa- } \\
\text { tions } \\
N\end{array}$} & \multicolumn{2}{|c|}{ Burns and Walters } & \multicolumn{2}{|c|}{ Jackson } & \multirow{2}{*}{$\begin{array}{l}\text { Term } \\
\text { combination }\end{array}$} & \multirow{2}{*}{$\begin{array}{c}\text { Wave } \\
\text { number } \\
\text { in } \\
\text { vacuum }\end{array}$} \\
\hline & & $\lambda$ & $N$ & $\lambda$ & $N$ & & \\
\hline $\begin{array}{l}2749.325 \\
2746.9823 \\
2746.4833 \\
2739.5467 \\
2735.473\end{array}$ & $\begin{array}{l}12 \\
13 \\
14 \\
25 \\
15\end{array}$ & $\begin{array}{l}322 \\
983 \\
482 \\
546 \\
475\end{array}$ & $\begin{array}{l}11 \\
18 \\
18 \\
19 \\
19\end{array}$ & 476 & 5 & $\begin{array}{l}a^{4} \mathrm{D}_{3}-a^{4} \mathrm{~F}_{4}^{\circ} \\
a^{4} \mathrm{D}_{3}-a^{4} \mathrm{D}_{3}^{\circ} \\
a^{4} \mathrm{D}_{2}-a^{4} \mathrm{~F}_{3}^{\circ} \\
a^{4} \mathrm{D}_{4}-a^{4} \mathrm{D}_{4}^{\circ} \\
a^{5} \mathrm{~F}_{4}-d^{5} \mathrm{D}_{3}^{\circ}\end{array}$ & $\begin{array}{l}36361.83 \\
36392.842 \\
36399.454 \\
36491.611 \\
36545.95\end{array}$ \\
\hline $\begin{array}{l}2727.540 \\
2723.5770 \\
2718.4352 \\
2714.413 \\
2711.6548\end{array}$ & $\begin{array}{r}4 \\
6 \\
12 \\
6 \\
9\end{array}$ & $\begin{array}{l}538 \\
576 \\
435 \\
411 \\
654\end{array}$ & $\begin{array}{l}19 \\
11 \\
15 \\
16 \\
17\end{array}$ & 577 & 2 & $\begin{array}{c}a^{4} \mathrm{D}_{3}-a^{4} \mathrm{D}_{2}^{\circ} \\
a^{5} \mathrm{D}_{2}-b^{5} \mathrm{P}_{1}^{\circ} \\
a^{5} \mathrm{~F}_{2}-47 \mathrm{R}_{1}^{\circ} \\
a^{4} \mathrm{D}_{4}-a^{4} \mathrm{D}_{3}^{\circ} \\
a^{5} \mathrm{~F}_{4}-50 \mathrm{R}_{5}^{\circ}\end{array}$ & $\begin{array}{l}36652.24 \\
36705.568 \\
36774.989 \\
36829.48 \\
36866.941\end{array}$ \\
\hline $\begin{array}{l}2706.5812 \\
2699.1060 \\
2689.2117 \\
2679.0608 \\
\text { 2673. } 2127\end{array}$ & $\begin{array}{r}11 \\
16 \\
26 \\
26 \\
6\end{array}$ & $\begin{array}{l}582 \\
104 \\
212 \\
061 \\
213\end{array}$ & $\begin{array}{r}19 \\
17 \\
14 \\
20 \\
6\end{array}$ & $\begin{array}{l}108 \\
212 \\
063\end{array}$ & $\begin{array}{l}8 \\
7 \\
9\end{array}$ & $\begin{array}{l}a^{5} \mathrm{~F}_{3}-51 \mathrm{R}_{2} \\
a^{5} \mathrm{~F}_{4}-49 \mathrm{R}_{4}^{\circ} \\
a^{5} \mathrm{~F}_{4}-48 \mathrm{R}_{3}^{\circ} \\
a^{5} \mathrm{~F}_{5}-50 R_{5}^{\circ} \\
a^{5} \mathrm{~F}_{1}-c^{3} \mathrm{D}_{1}^{\circ}\end{array}$ & $\begin{array}{l}36936.043 \\
37038.333 \\
37174.597 \\
37315.443 \\
37397.072\end{array}$ \\
\hline $\begin{array}{l}\text { 2662. } 0563 \\
2651.7059 \\
2647.5576 \\
2643.9972 \\
2635.8082\end{array}$ & $\begin{array}{r}14 \\
7 \\
10 \\
22 \\
15\end{array}$ & $\begin{array}{l}056 \\
706 \\
557 \\
999 \\
808\end{array}$ & $\begin{array}{l}14 \\
12 \\
13 \\
15 \\
15\end{array}$ & $\begin{array}{r}\text { 4. } 005 \\
807\end{array}$ & $\begin{array}{l}7 \\
8\end{array}$ & $\begin{array}{l}a^{5} \mathrm{~F}_{3}-c^{3} \mathrm{D}_{2}^{\circ} \\
a^{5} \mathrm{~F}_{3}-b^{3} \mathrm{G}_{4}^{\circ} \\
a^{5} \mathrm{D}_{3}-b^{3} \mathrm{D}_{3}^{\circ} \\
a^{5} \mathrm{~F}_{1}-c^{5} \mathrm{G}_{2}^{2} \\
a^{5} \mathrm{~F}_{2}-c^{5} \mathrm{G}_{3}^{\circ}\end{array}$ & $\begin{array}{l}37553.789 \\
37700.363 \\
37759.431 \\
37810.273 \\
37927.736\end{array}$ \\
\hline $\begin{array}{l}\text { 2628. } 2923 \\
2625.6663 \\
2621.6690 \\
2617.6160 \\
2613.8240\end{array}$ & $\begin{array}{r}27 \\
24 \\
8 \\
16 \\
13\end{array}$ & $\begin{array}{l}292 \\
666 \\
667 \\
615 \\
823\end{array}$ & $\begin{array}{l}11 \\
18 \\
21 \\
17 \\
23\end{array}$ & $\begin{array}{l}292 \\
668\end{array}$ & $\begin{array}{l}3 \\
5\end{array}$ & $\begin{array}{l}a^{6} \mathrm{D}_{1}-a^{6} \mathrm{D}_{2}^{\circ} \\
a^{6} \mathrm{D}_{4}-a^{6} \mathrm{D}_{5}^{\circ} \\
a^{6} \mathrm{D}_{1}-a^{6} \mathrm{D}_{1}^{\circ} \\
a^{6} \mathrm{D}_{3}-a^{6} \mathrm{D}_{3}^{\circ} \\
a^{6} \mathrm{D}_{2}-a^{6} \mathrm{D}_{1}^{\circ}\end{array}$ & $\begin{array}{l}38036.188 \\
38074.227 \\
38132.274 \\
38191.328 \\
38246.715\end{array}$ \\
\hline $\begin{array}{l}2611.8725 \\
2598.3689 \\
2585.8753 \\
2584.5349 \\
2576.1033\end{array}$ & $\begin{array}{r}14 \\
8 \\
9 \\
7 \\
6\end{array}$ & $\begin{array}{l}873 \\
368 \\
877 \\
538\end{array}$ & $\begin{array}{l}19 \\
20 \\
19 \\
19\end{array}$ & $\begin{array}{l}872 \\
369 \\
876 \\
535\end{array}$ & $\begin{array}{r}3 \\
9 \\
10 \\
8\end{array}$ & $\begin{array}{l}a^{6} \mathrm{D}_{4}-a^{6} \mathrm{D}_{4}^{\circ} \\
a^{6} \mathrm{D}_{4}-a^{6} \mathrm{D}_{3}^{\circ} \\
a^{6} \mathrm{D}_{5}-a^{6} \mathrm{D}_{4}^{\circ} \\
a^{5} \mathrm{~F}_{5}-c^{5} \mathrm{G}_{6}^{\circ} \\
(\mathrm{FeI})\end{array}$ & $\begin{array}{l}38275.290 \\
38474.191 \\
38660.066 \\
38680.115 \\
38806.705\end{array}$ \\
\hline $\begin{array}{l}2575.7442 \\
2562.5348 \\
2551.0936 \\
2542.1007 \\
2530.6938\end{array}$ & $\begin{array}{r}7 \\
11 \\
11 \\
11 \\
10\end{array}$ & $\begin{array}{l}744 \\
533 \\
090 \\
101 \\
691\end{array}$ & $\begin{array}{l}23 \\
17 \\
23 \\
17 \\
14\end{array}$ & $\begin{array}{l}534 \\
102 \\
692\end{array}$ & $\begin{array}{l}8 \\
2 \\
1\end{array}$ & $\begin{array}{l}(\mathrm{FeI}) \\
a^{4} \mathrm{D}_{4}-a^{4} \mathrm{P}_{3}^{\circ} \\
(\mathrm{Fe} \mathrm{I}) \\
(\mathrm{Fe} \mathrm{I}) \\
(\mathrm{Fe} \mathrm{I})\end{array}$ & $\begin{array}{l}38812.116 \\
39012.172 \\
39187.122 \\
39325.739 \\
39502.984\end{array}$ \\
\hline $\begin{array}{l}2519.6279 \\
2507.8987 \\
2496.5324 \\
2487.0643 \\
2474.8131\end{array}$ & $\begin{array}{r}11 \\
11 \\
11 \\
8 \\
11\end{array}$ & $\begin{array}{l}627 \\
898 \\
534 \\
064 \\
813\end{array}$ & $\begin{array}{l}19 \\
20 \\
20 \\
17 \\
16\end{array}$ & $\begin{array}{l}900 \\
533 \\
814\end{array}$ & $\begin{array}{l}7 \\
8 \\
8\end{array}$ & $\begin{array}{l}(\mathrm{Fe}) \\
(\mathrm{Fe} \mathrm{I}) \\
(\mathrm{Fe} \mathrm{I}) \\
(\mathrm{Fe} \mathrm{I}) \\
(\mathrm{Fe} \mathrm{I})\end{array}$ & $\begin{array}{l}39676.464 \\
39862.013 \\
40043.485 \\
41195.915 \\
40394.883\end{array}$ \\
\hline $\begin{array}{l}2468.8782 \\
2465.1479 \\
2457.5956 \\
2453.4746 \\
2447.7086\end{array}$ & $\begin{array}{l}11 \\
11 \\
10 \\
11 \\
10\end{array}$ & $\begin{array}{l}878 \\
148 \\
595 \\
472 \\
707\end{array}$ & $\begin{array}{l}20 \\
22 \\
18 \\
20 \\
17\end{array}$ & $\begin{array}{l}879 \\
148 \\
595\end{array}$ & $\begin{array}{l}7 \\
8 \\
8\end{array}$ & $\begin{array}{l}(\mathrm{Fe} \mathrm{I}) \\
a^{5} \mathrm{~F}_{4}-142 \mathrm{~B} \\
(\mathrm{Fe} \mathrm{I}) \\
(\mathrm{Fe} \mathrm{I}) \\
a^{5} \mathrm{D}_{4}-c^{5} \mathrm{~F}_{3}^{\circ}\end{array}$ & $\begin{array}{l}40491.982 \\
40553.249 \\
40677.862 \\
40746.181 \\
40842.159\end{array}$ \\
\hline $\begin{array}{l}2443.8707 \\
2442.5674 \\
2438.1811 \\
2431.025 \\
2413.3087\end{array}$ & $\begin{array}{r}8 \\
9 \\
11 \\
4 \\
18\end{array}$ & $\begin{array}{l}870 \\
567 \\
179 \\
023 \\
308\end{array}$ & $\begin{array}{l}18 \\
19 \\
15 \\
12 \\
18\end{array}$ & 309 & 10 & $\begin{array}{l}a^{5} \mathrm{~F}_{5}-26 \mathrm{R}_{\ddagger} \\
(\mathrm{Fe} \mathrm{I}) \\
a^{5} \mathrm{~F}_{5}-142 \mathrm{~B} \\
(\mathrm{Fe} \mathrm{I}) \\
a^{6} \mathrm{D}_{1}-a^{6} \mathrm{~F}_{2}^{\circ}\end{array}$ & $\begin{array}{l}\text { 40906. } 292 \\
40928.117 \\
41001.740 \\
41122.43 \\
\text { 41424. } 284\end{array}$ \\
\hline $\begin{array}{l}2411.0663 \\
2410.5172 \\
2406.6593 \\
2404.430 \\
2399.2396\end{array}$ & $\begin{array}{r}17 \\
11 \\
20 \\
3 \\
12\end{array}$ & $\begin{array}{l}064 \\
518 \\
659 \\
429 \\
239\end{array}$ & $\begin{array}{l}22 \\
13 \\
18 \\
19 \\
19\end{array}$ & $\begin{array}{l}066 \\
517 \\
657\end{array}$ & $\begin{array}{l}7 \\
8 \\
3\end{array}$ & $\begin{array}{c}a^{6} \mathrm{D}_{1}-a^{6} \mathrm{~F}_{1} \\
a^{6} \mathrm{D}_{2}-a^{6} \mathrm{~F}_{3}^{\circ} \\
a^{6} \mathrm{D}_{2}-a^{6} \mathrm{~F}_{2}^{\circ} \\
a^{6} \mathrm{D}_{2}-a^{6} \mathrm{~F}_{1}^{\circ} \\
a^{6} \mathrm{D}_{3}-a^{6} \mathrm{~F}_{3}^{\circ}\end{array}$ & $\begin{array}{l}41462.808 \\
41472.250 \\
41538.728 \\
41577.24 \\
41667.176\end{array}$ \\
\hline
\end{tabular}


TABLE 4.-Interference measurements of wave length in the ultraviolet spectrum of iron-Continued

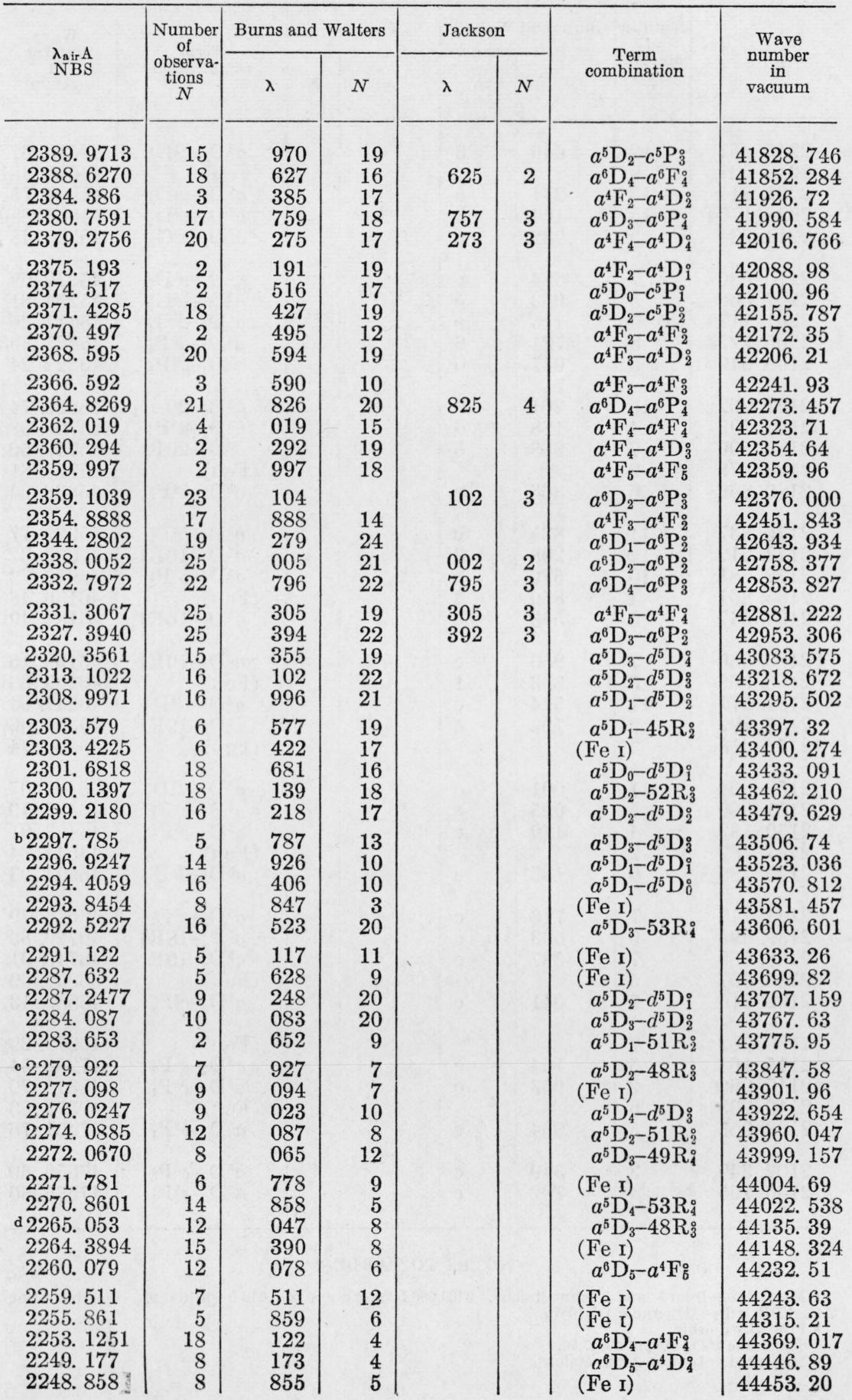


TABLE 4.-Interference measurements of wave length in the ultraviolet spectrum of iron-Continued

\begin{tabular}{|c|c|c|c|c|c|c|c|}
\hline \multirow{2}{*}{$\begin{array}{l}\lambda_{\text {air }} A \\
\text { NBS }\end{array}$} & \multirow{2}{*}{$\begin{array}{c}\text { Number } \\
\text { of } \\
\text { observa- } \\
\text { tions } \\
N\end{array}$} & \multicolumn{2}{|c|}{ Burns and Walters } & \multicolumn{2}{|c|}{ Jackson } & \multirow{2}{*}{$\begin{array}{l}\text { Term } \\
\text { combination }\end{array}$} & \multirow{2}{*}{$\begin{array}{c}\text { Wave } \\
\text { number } \\
\text { in } \\
\text { vacuum }\end{array}$} \\
\hline & & $\lambda$ & $N$ & $\lambda$ & $N$ & & \\
\hline $\begin{array}{l}2245.651 \\
2240.627 \\
2231.211 \\
2228.1704 \\
2211.234\end{array}$ & $\begin{array}{r}12 \\
9 \\
13 \\
13 \\
5\end{array}$ & $\begin{array}{l}211 \\
164 \\
232\end{array}$ & $\begin{array}{l}5 \\
3 \\
\text { c }\end{array}$ & & & $\begin{array}{l}a^{5} \mathrm{D}_{2}-c^{3} \mathrm{D}_{3}^{\circ} \\
(\mathrm{Fe} \mathrm{I}) \\
a^{5} \mathrm{D}_{3}-c^{3} \mathrm{D}_{3}^{\circ} \\
a^{5} \mathrm{D}_{3}-c^{3} \mathrm{D}_{2}^{\circ} \\
a^{5} \mathrm{D}_{2}-c^{5} \mathrm{G}_{3}^{\circ}\end{array}$ & $\begin{array}{l}44516.67 \\
44616.48 \\
44804.75 \\
44865.880 \\
45209.48\end{array}$ \\
\hline $\begin{array}{l}2210.686 \\
2207.068 \\
2201.117 \\
2200.7227 \\
2196.040\end{array}$ & $\begin{array}{l}7 \\
5 \\
5 \\
8 \\
5\end{array}$ & $\begin{array}{l}684 \\
063 \\
113 \\
721 \\
037\end{array}$ & $\begin{array}{l}\mathrm{c} \\
\mathrm{c} \\
\mathrm{c} \\
6 \\
6\end{array}$ & & & $\begin{array}{l}a^{5} \mathrm{D}_{4}-c^{3} \mathrm{D}_{3}^{2} \\
a^{5} \mathrm{D}_{4}-b^{3} \mathrm{G}_{5}^{0} \\
a^{5} \mathrm{D}_{3}-c^{5} \mathrm{G}_{4}^{\circ} \\
a^{5} \mathrm{D}_{1}-d^{5} \mathrm{P}_{2}^{0} \\
a^{5} \mathrm{D}_{1}-d^{5} \mathrm{P}_{1}^{\circ}\end{array}$ & $\begin{array}{l}45220.69 \\
45294.81 \\
45417.26 \\
45425.393 \\
45522.24\end{array}$ \\
\hline $\begin{array}{l}\text { 2191. } 202 \\
2187.192 \\
2186.890 \\
2183.979 \\
2180.866\end{array}$ & $\begin{array}{r}10 \\
4 \\
7 \\
9 \\
6\end{array}$ & $\begin{array}{l}201 \\
188 \\
888 \\
863\end{array}$ & $\begin{array}{l}2 \\
6 \\
5\end{array}$ & & & $\begin{array}{c}a^{5} \mathrm{D}_{0}-20 \mathrm{R}_{1} \\
a^{5} \mathrm{D}_{2}-d^{5} \mathrm{P}_{1}^{\circ} \\
a^{5} \mathrm{D}_{1}-20 \mathrm{R}_{1}^{\circ} \\
(\mathrm{Fe} \mathrm{I}) \\
a^{5} \mathrm{D}_{1}-b^{3} \mathrm{P}_{2}^{\circ}\end{array}$ & $\begin{array}{l}45622.74 \\
45706.38 \\
45712.69 \\
45773.61 \\
45838.94\end{array}$ \\
\hline $\begin{array}{l}2176.837 \\
2173.212 \\
2172.581 \\
2165.861 \\
2164.547\end{array}$ & $\begin{array}{r}11 \\
12 \\
10 \\
4 \\
8\end{array}$ & $\begin{array}{l}835 \\
208 \\
579 \\
859 \\
543\end{array}$ & $\begin{array}{l}\text { c } \\
3 \\
\text { c } \\
3 \\
\text { c }\end{array}$ & & & $\begin{array}{c}a^{5} \mathrm{D}_{0}-b^{3} \mathrm{P}_{1} \\
a^{5} \mathrm{D}_{1}-16 \mathrm{R}_{2}^{\circ} \\
a^{5} \mathrm{D}_{1}-b^{3} \mathrm{P}_{1}^{\circ} \\
(\mathrm{Fe} \mathrm{I}) \\
a^{5} \mathrm{D}_{2}-16 \mathrm{R}_{2}\end{array}$ & $\begin{array}{l}45923.77 \\
46000.37 \\
46013.72 \\
46156.48 \\
46184.49\end{array}$ \\
\hline $\begin{array}{r}2163.860 \\
2163.368 \\
2161.577 \\
2157.792 \\
\text { d } 2154.458\end{array}$ & $\begin{array}{r}7 \\
5 \\
11 \\
9 \\
3\end{array}$ & $\begin{array}{l}856 \\
363 \\
574 \\
793\end{array}$ & $\begin{array}{l}\mathrm{c} \\
1 \\
\mathrm{c} \\
4\end{array}$ & & & $\begin{array}{l}a^{5} \mathrm{D}_{0}-10 \mathrm{R}_{1} \\
(\mathrm{Fe} \mathrm{I}) \\
a^{5} \mathrm{D}_{1}-d^{3} \mathrm{D}_{2}^{\circ} \\
a^{5} \mathrm{D}_{3}-19 \mathrm{R}_{3}^{\circ} \\
(\mathrm{Fe} \mathrm{I})\end{array}$ & $\begin{array}{l}46199.15 \\
46209.66 \\
46247.94 \\
46329.06 \\
46400.74\end{array}$ \\
\hline $\begin{array}{l}2153.004 \\
2151.099 \\
2150.182 \\
2147.787 \\
2145.188\end{array}$ & $\begin{array}{r}11 \\
5 \\
4 \\
2 \\
9\end{array}$ & $\begin{array}{l}001 \\
095 \\
179 \\
185\end{array}$ & $\begin{array}{l}\text { c } \\
\text { c } \\
\text { c }\end{array}$ & & & $\begin{array}{l}a^{5} \mathrm{D}_{2}-d^{3} \mathrm{D}_{2}^{\circ} \\
a^{5} \mathrm{D}_{3}-c^{3} \mathrm{~F}_{4}^{\circ} \\
a^{5} \mathrm{D}_{2}-c^{3} \mathrm{~F}_{2}^{\circ} \\
(\mathrm{Fe} \mathrm{I}) \\
a^{5} \mathrm{D}_{3}-d^{3} \mathrm{D}_{3}^{\circ}\end{array}$ & $\begin{array}{l}46432.07 \\
46473.19 \\
46493.01 \\
46544.84 \\
46601.23\end{array}$ \\
\hline $\begin{array}{l}2141.715 \\
2139.695 \\
2138.589 \\
2135.957 \\
2132.015\end{array}$ & $\begin{array}{l}7 \\
9 \\
7 \\
5 \\
9\end{array}$ & $\begin{array}{l}713 \\
693 \\
587 \\
011\end{array}$ & $\begin{array}{l}\text { c } \\
\text { c } \\
\text { c }\end{array}$ & & & $\begin{array}{c}a^{5} \mathrm{D}_{3}-c^{3} \mathrm{~F}_{3}^{\circ} \\
a^{5} \mathrm{D}_{4}-18 \mathrm{R}_{4}^{\circ} \\
a^{5} \mathrm{D}_{4}-19 \mathrm{R}_{3}^{\circ} \\
(\mathrm{Fe} \mathrm{I}) \\
a^{5} \mathrm{D}_{4}-c^{3} \mathrm{~F}_{4}^{\circ}\end{array}$ & $\begin{array}{l}46676.79 \\
46720.85 \\
46745.01 \\
46802.60 \\
46889.13\end{array}$ \\
\hline $\begin{array}{r}2130.962 \\
2115.168 \\
\text { d } 2112.966 \\
2110.233 \\
2108.955\end{array}$ & $\begin{array}{l}7 \\
5 \\
2 \\
6 \\
5\end{array}$ & $\begin{array}{l}164 \\
963 \\
954\end{array}$ & $\begin{array}{l}\text { c } \\
\text { c }\end{array}$ & & & $\begin{array}{l}(\mathrm{Fe} \mathrm{I}) \\
a^{5} \mathrm{D}_{2}-e^{5} \mathrm{P}_{3}^{\circ} \\
a^{5} \mathrm{D}_{0}-e^{5} \mathrm{P}_{1}^{\circ} \\
(\mathrm{Fe} \mathrm{I}) \\
a^{5} \mathrm{D}_{1}-e^{5} \mathrm{P}_{1}^{\circ}\end{array}$ & $\begin{array}{l}46912.29 \\
47262.54 \\
47311.79 \\
47373.06 \\
47401.76\end{array}$ \\
\hline $\begin{array}{l}2102.349 \\
2100.795\end{array}$ & $\begin{array}{l}3 \\
4\end{array}$ & $\begin{array}{l}349 \\
792\end{array}$ & $\begin{array}{l}\text { c } \\
\text { c }\end{array}$ & & & $\begin{array}{l}a^{5} \mathrm{D}_{3}-e^{5} \mathrm{P}_{3}^{\circ} \\
a^{5} \mathrm{D}_{2}-e^{5} \mathrm{P}_{1}^{\circ}\end{array}$ & $\begin{array}{l}47550.69 \\
47585.86\end{array}$ \\
\hline
\end{tabular}

NOTES TO TABLE 4

a Mean value from 5- and 7.5-mm étalons. 3160.060 from $2 \mathrm{~mm}$ and 0.049 from $10 \mathrm{~mm}$. Possibly 3 lines, $a^{3} \mathrm{G}_{4}-163 \mathrm{~B}, a^{5} \mathrm{~F}_{2}-c^{5} \mathrm{D}_{3}^{\circ}$, and $a^{7} \mathrm{D}_{5}^{\circ}-10 \mathrm{~W}_{4}$.

b Probably double.

- Spark line $a^{6} \mathrm{D}_{4}-a^{4} \mathrm{~F}_{5}^{\circ}$ at 43847.76 .

d Measured only with 2-mm étalons, 


\section{REFERENCES}

[1] H. Kayser and C. Runge, Abhandl. Berlin Akad. (1888 and 1890).

[2] H. Kayser and H. Konen, Handbuch der Spectroscopie $\mathbf{y , ~ 4 0 5 - 4 9 7 ~ ( S . ~}$ Hirzel, Leipzig, 1934).

[3] Trans. Int. Astron. Union 3, 77-102 (1928).

[4] K. Burns and F. M. Walters, Jr., Pub. Allegheny Obs. 6, 159-211 (1929); 8, 39-64 (1931).

(Although these observations were made with the vacuum iron arc, most of the values may be converted to atmospheric iron arc by calculation from spectral terms corrected for a pressure of one atmosphere (H. D. Babcock, Astrophys. J. 67, 240; 1928).

[5] C. V. Jackson, Proc. Roy. Śc. (London) [A] 130, 395-410 (1931); [A] 133, $553-564(1931)$.

[6] H. Buisson and Ch. Fabry, Astrophys. J. 28, 169 (1908).

[7] K. Burns, BS Sci. Pap. 12, 179-197 (1915) S251.

[8] H. Pressentin, Z. Physik 60, 125-136 (1930).

[9] Proces-Verbaux, Comité Int. Poids et Mesures 91 (1935).

[10] Trans. Int. Astron. Union 2, 36 (1925).

[11] W. F. Meggers and K. Burns, BS Sci. Pap. 18, 191-196 (1922) S 441.

[12] W. F. Meggers, BS Sci. Pap. 12, 198 (1915) S251.

13] Trans. Int. Astron. Union 5, 86 (1935).

[14] Trans. Int. Astron. Union 5, 87 (1935).

[15] C. J. Humphreys, BS J. Research 5, 1044 (1930) RP245.

[16] W. F. Meggers and C. G. Peters, BS Sci. Pap. 14, 724 (1918) S327.

[17] C. V. Jackson, Proc. Roy. Soc. (London) [A] 133, 555-556 (1931).

[18] F. Goos, Astrophys. J. 38, 141 (1913).

[19] L. Lang, Z. wiss. Phot. 15, 223-292 (1915).

[20] J. DeGier and P. Zeeman, Proc. Roy. Acad. Sci. (Amsterdam) 38, 959-960 (1935).

[21] C. and M. Cuthbertson, Phil. Trans. [A] 213, 16 (1913).

[22] Trans. Int. Astron. Union 4, 60 (1932).

[23] M. A. Catalán, Anal. Soc. Esp. Fis. Quim. 28, 1239 (1930).

[24] H. N. Russell, Astrophys. J. 64, 194 (1926].

Washington, January 27, 1937. 